\title{
Perreyia flavipes larvae toxicity ${ }^{1}$
}

\author{
Djeison L. Raymundo ${ }^{2 *}$, Pedro S. Bezerra Jr², Paulo M. Bandarra ${ }^{3}$, André G.C. Dalto ${ }^{3}$, \\ Mauro P. Soares ${ }^{4}$, Cláudio E.F. da Cruz ${ }^{3}$ and David Driemeier ${ }^{3}$
}

\begin{abstract}
Raymundo D.L., Bezerra Jr P.S., Bandarra P.M., Dalto A.G.C., Soares M.P., Cruz C.E.F. \& Driemeier D. 2012. Perreyia flavipes larvae toxicity. Pesquisa Veterinária Brasileira 32(8):735-738. Setor de Patologia Veterinária, Departamento de Patologia Clínica Veterinária, Faculdade de Veterinária, Universidade Federal do Rio Grande do Sul, Av. Bento Gonçalves 9090, Porto Alegre, RS 95320-000, Brazil. E-mail: djeison.raymundo@dmv.ufla.br

Fresh or thawed Perreyia flavipes larvae were ground and mixed with water and orally administered to sheep. At $5 \mathrm{mg} / \mathrm{kg}$, neither clinical nor enzymatic changes were observed. Unique doses of 7.5 and $10 \mathrm{mg} / \mathrm{kg}$ induced characteristic clinical signs of Perreyia sp. larvae poisoning, increased GGT and AST values, and decreased glycemic curves. However, doses of 5,10 , and $15 \mathrm{mg} / \mathrm{kg}$ repeated at 30 or 15 days intervals caused no disease and mild disease followed by death, respectively. These findings indicate that these animals probably developed some degree of tolerance to the toxins in P. flavipes larvae. Ultrastructural examination of liver revealed proliferation of the smooth endoplasmic reticulum in the hepatocytes, which may be associated with an increased ability to metabolize toxins and could consequently lead to the tolerance observed in the present study. Further investigations may elucidate whether such tolerance effects could be applied as a control measure for $P$. flavipes poioning or other hepatotoxic diseases. In addition, clinicopathological findings were discussed.
\end{abstract}

INDEX TERMS: Perreyia flavipes larvae, poisoning, tolerance, sheep.

RESUMO.- [Toxicidade das larvas de Perreyia flavipes.] Larvas frescas ou descongeladas de Perreyia flavipes foram moídas e misturadas com água e administradas de forma oral a ovinos. Com $5 \mathrm{mg} / \mathrm{kg}$, não foram observados achados clínicos ou enzimáticos. Doses únicas de 7,5 e 10mg/ kg induziram a sinais clínicos característicos de intoxicação pelas larvas de Perreyia sp., os níveis de GGT e AST estavam aumentados e as curvas glicêmicas estavam diminuídas. Entretanto, doses de 5, 10 e $15 \mathrm{mg} / \mathrm{kg}$ repetidas em intervalos de 30 ou 15 dias não causou doença ou causou doença discreta seguida de morte, respectivamente. Estes achados indicam que estes animais provavelmente desenvolveram

\footnotetext{
${ }^{1}$ Received on March 24, 2012.

Accepted for publication on April 10, 2012.

${ }^{2}$ Departamento de Medicina Veterinária, Universidade Federal de Lavras (UFLA), Cx. Postal 3037, Lavras, MG 37200-000, Brazil. *Autor para correspondência: djeison.raymundo@dmv.ufla.br

${ }^{3}$ Departamento de Patologia Clínica Veterinária, Faculdade de Veterinária, Universidade Federal do Rio Grande do Sul (UFRGS), Av. Bento Gonçalves 9090, Porto Alegre, RS 95320-000, Brazil.

${ }^{4}$ Laboratório Regional de Diagnóstico, Faculdade de Veterinária, Universidade Federal de Pelotas (UFPel), Campus Universitário s/n, Pelotas, RS 96010-900, Brazil.
}

algum grau de tolerância para as toxinas presentes nas larvas de $P$. flavipes. 0 exame ultraestrutural do fígado revelou proliferação do retículo endoplasmático liso de hepatócitos, o que pode ser associado a um aumento na capacidade de metabolizar toxinas e conseqüentemente levar à tolerância observada no presente estudo. Outras investigações poderão esclarecer se os efeitos de tal tolerância poderiam ser aplicados como medida de controle da intoxicação por P. flavipes ou outras doenças hepatotóxicas. Além disso, os resultados clínico-patológicos foram discutidos.

TERMOS DE INDEXAÇÃO: Larvas de Perreyia flavipes, intoxicação, tolerância, ovinos.

\section{INTRODUCTION}

The ingestion of larvae from insects of the suborder Symphyta (sawfly) (order Hymenoptera) has caused worldwide outbreaks of acute hepatic necrosis in livestock (Dadswell et al. 1985, Thamsborg et al. 1987, Smith 1990, Dutra et al. 1997). Larvae have been linked to spontaneous poisoning and deaths in different species and countries including the following: larvae of Lophyrotoma interrupta (Pergidae) poisoning cattle and sheep in Australia (Da- 
dswell et al. 1985, McKenzie et al. 1985), larvae of Arge pullata (Argidae) poisoning sheep and goats in Denmark (Thamsborg et al. 1987), larvae of Perreyia lepida (Pergidae) suspected of poisoning pigs in Brazil (Camargo, 1955), and larvae of Perreyia flavipes (Pergidae) poisoning cattle and sheep in Uruguay (Dutra 1997, Dutra et al. 1997) as well as cattle (Raymundo et al. 2009, Soares et al. 2008), sheep (Raymundo et al. 2008) and pigs (Jonck et al. 2010) in Brazil. Experimental intoxication by Perreyia flavipes larvae has been conducted in pigs (Soares et al. 2001), cattle and sheep (Dutra 1997). Sawfly larval poisoning has been attributed to D-amino acid containing peptides (Kannan et al. 1988, Oelrichs et al. 1999). The palatability of the insect in association with nutritional deficiencies has been indicated as the main risk factor involved in the intoxications (McKenzie et al. 1985, Dutra 1997). This communication reports toxicity aspects of experimentally induced P. flavipes larvae poisoning in sheep and discusses clinicopathological findings.

\section{MATERIALS AND METHODS}

Compact masses of sawfly larvae subsequently identified as Perreyia flavipes (Smith 1990) were collected in farms in Rio Grande do Sul and Santa Catarina, where outbreaks of $P$. flavipes poisoning in cattle and sheep had occurred. Seven 2-year-old mixed breed sheep were forced fed with fresh or thawed larvae (ground and mixed with water) through a syringe (with the top cut) as shown in Table 1. Hepatic biopsies were collected from sheep 5 and 6 before the first and after each dose and then submitted for ultrastructural study. Animals were clinically examined twice daily. Blood samples were collected before and after (twice daily) dosing sheep with larvae to determine glycemic curves and serum activities of gamma glutamyl transferase (GGT) and aspartate aminotransferase (AST). Necropsies were performed immediately after death and a number of tissue samples were collected, fixed in buffered $10 \%$ formalin, processed for histology, and stained by hematoxylin and eosin (Allen 1992).

\section{RESULTS}

A summary of the clinical evolution is presented in Table 1. Clinical signs included anorexia, apathy, weakness, reluctance to move, difficulties in standing, palpebral ptosis, muscular tremors (especially head and neck), dried feces, increased salivation, depression, sternal or lateral recumbence, nystagmus, opisthotonos, paddling, vocalization, coma and death. Figure 1 includes the GGT and AST analysis as well as the glycemic curves. Main macroscopic lesions were ascites, hepatomegaly, yellowish liver, enhanced lobular pattern, diffuse hepatic subcapsular congestion and hemorrhage, gallbladder distended and walls edematous. There were also varying degrees of hemorrhage and edema scattered in several organs. Prominent microscopic lesions
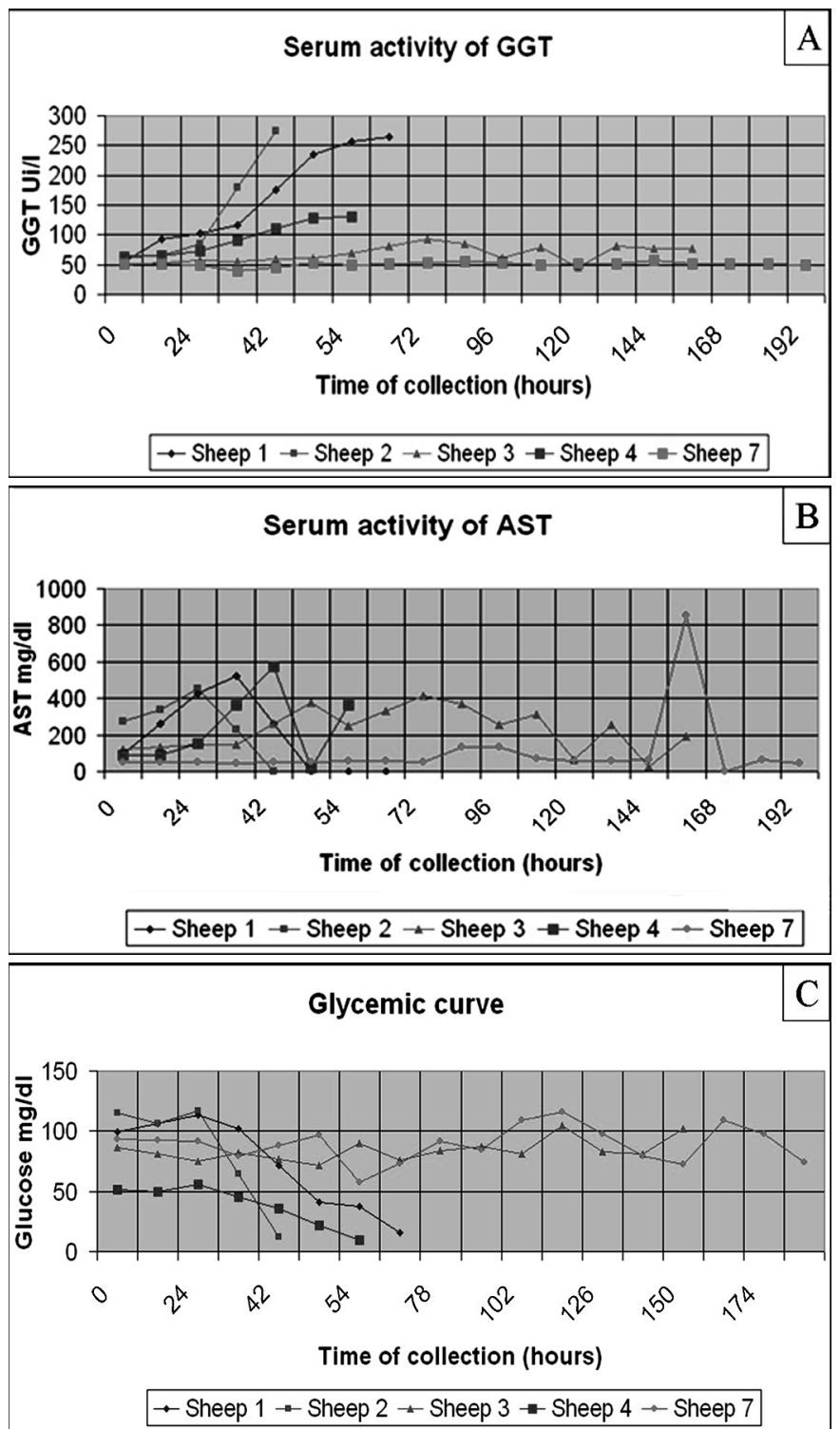

Fig.1. (A) Serum activities of gamma glutamyl transferase, (B) aspartate aminotransferase, and (C) glycemic curves of sheep experimentally poisoned with Perreyia flavipes larvae.

Table 1. Experimental intoxication of sheep with Perreyia flavipes larvae. Data concerning animals, doses, larvae, and clinical evolution

\begin{tabular}{|c|c|c|c|c|c|c|c|c|c|}
\hline Sheep & $\begin{array}{l}\text { Dose } 1 \\
(\mathrm{~g} / \mathrm{kg})\end{array}$ & $\begin{array}{l}\text { Time (h) to } \\
\text { clinical signs }\end{array}$ & $\begin{array}{l}\text { Dose } 2 \\
(\mathrm{~g} / \mathrm{kg})\end{array}$ & $\begin{array}{l}\text { Time }(\mathrm{h}) \text { to } \\
\text { clinical signs }\end{array}$ & $\begin{array}{l}\text { Dose } 3 \\
\text { (g/kg) }\end{array}$ & $\begin{array}{l}\text { Time }(\mathrm{h}) \text { to } \\
\text { clinical signs }\end{array}$ & $\begin{array}{l}\text { Time }(\mathrm{h}) \text { to } \\
\text { death }\end{array}$ & Larvae & $\begin{array}{c}\text { Total } \\
\text { dose }(\mathrm{g})\end{array}$ \\
\hline $1^{*}$ & 10 & 47 & - & - & - & - & 61 & Fresh & 395 \\
\hline $3 *$ & 5 & No signs & - & - & - & - & Not died & Fresh & 205 \\
\hline $4^{*}$ & 10 & 42 & - & - & - & - & 49 & Thawed & 285 \\
\hline $5 \dagger$ & 5 & No signs & 10 & No signs & 15 & No signs & Not died & Thawed & 1221 \\
\hline 7 & 0 & - & - & - & - & - & Not died & Control & Control \\
\hline
\end{tabular}

* Sheep receiving single doses. $†$ Sheep dosed at 30 days intervals. ¥ Sheep dosed at 15 days intervals. 

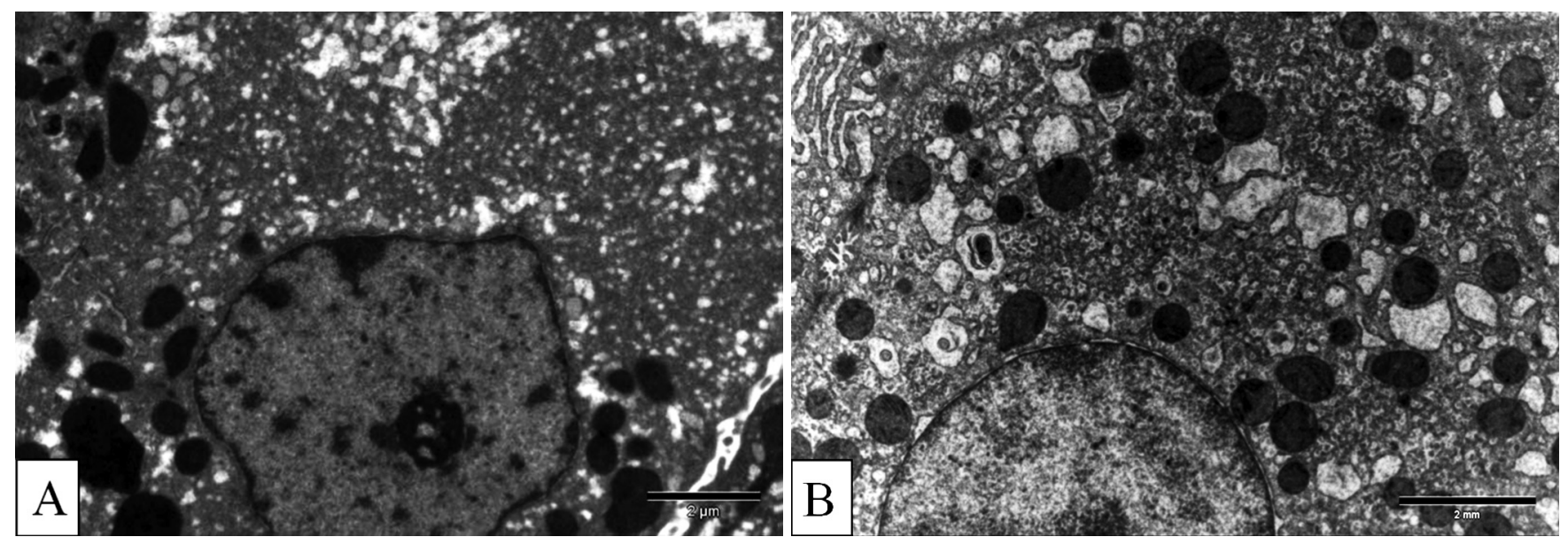

Fig.2. Experimentally induced Perreyia flavipes larvae poisoning. (A) Electron micrograph showing hepatocyte with hypertrophic smooth endoplasmic reticulum (Sheep 6). (B) Hepatocyte with normal smooth endoplasmic reticulum (Sheep 7).

included centrilobular coagulative or massive necrosis associated with centrilobular congestion and hemorrhage. Necrotic hepatocytes had vacuolated cytoplasms and nuclei, which were also pyknotic with condensed chromatin, karyorrhexis or karyolysis. Vacuolated renal tubular cells and lymphoid depletion associated with diffuse necrosis of the germinal centers were also observed in lymphoid tissues. Ultrastructural evaluations of biopsy sections showed moderate $(7$ days after the $5 \mathrm{~g} / \mathrm{kg}$ dose) and severe $(7$ days after the $10 \mathrm{~g} / \mathrm{kg}$ dose) proliferation of the smooth endoplasmic reticulum (Fig. 2). Sinusoidal dilatation and a few necrotic hepatocytes could be observed 7 days after the $10 \mathrm{~g} / \mathrm{kg}$ dose.

\section{DISCUSSION}

Clinicopathological findings were comparable to those observed in spontaneous $P$. flavipes poisoning in sheep (Raymundo et al. 2008, Dutra et al. 1997). The smallest toxic dose (STD) of Perreyia flavipes larvae to sheep was $7.5 \mathrm{~g} / \mathrm{kg}$. Similar results were reported for toxicity of Lophyrotoma interrupta and Arge pullata larvae to ruminants (Mckenzie 1985, Thamsborg et al. 1987). As previously suggested (Raymundo et al., 2008), sheep were more susceptible to $P$. flavipes larvae toxicity than were cattle, in which the STD was reported to be $40 \mathrm{~g} / \mathrm{kg}$ (Dutra et al., 1997). Neuromuscular disorders are common to many diseases and may be linked to hypoglycemia in association with hepatic detoxicant agents (Radostits et al. 2002). Hepatic necrosis may cause hypoglycemia because the remaining hepatic tissue may be insufficient to maintain adequate glycemic control (Colodel et al. 2000). Biochemical analysis of the blood was consistent with hepatic lesions, i.e., GGT and AST values were considerably elevated in the affected animals (Cornelius 1989). Similar AST serum profiles have been described for $P$. flavipes larvae toxicity in pigs (Soares et al. 2001). Electron microscopy revealed hepatic and vascular lesions. Although little is known regarding the mechanism of action of the toxins lophyrotomin and pergidin (Oelrichs et al. 1999) present in P. flavipes larvae, the typical cavitary edema observed in this cases suggests increased vascular permeability. Fibrin extravasation is an additional feature of those cavitary fluids because clots formed when the fluids were exposed to air. Similar findings have been described in intoxications by Xanthium cavanillesii (Loretti et al. 1999) and Microcystis aeruginosa (Jackson et al. 1985). Hemorrhages are expected consequences of acute hepatic intoxication because the liver maintains important hemostatic mechanisms (Badylak 1988). Sinusoidal dilatation has been observed in Xanthium cavanillesii (Loretti et al. 1999) and Microcystis aeruginosa (Jackson et al. 1985) poisonings and indicates vascular lesions. Proliferation of the smooth endoplasmic reticulum has been associated with an increased production of detoxifying enzymes (Cheville 1994) and could explain an increased ability to metabolize toxins, consequently leading to the development of apparent tolerance observed here. Sheep 6 developed mild disease after receiving $10 \mathrm{~g} / \mathrm{kg}$ but had only a few compromised hepatocytes, and the sheep was able to recuperate. The clinical evolution observed in sheep 5 and 6 suggested that these animals may have developed some degree of tolerance to the toxins in P. flavipes larvae. Although it is uncertain whether the mechanism is through hepatic detoxification or ruminal flora adaptation, sheep have been reported as being able to acquire tolerance to pyrrolizidine alkaloids (Cheeke 1998, Kellerman et al. 2005), especially after initial and light ingestions of plants containing these substances. This characteristic has been studied with the goal of developing control measures to poisoning by pyrrolizidine alkaloid-containing plants (Holloway 1968, Riet-Correa et al. 2007). The aforementioned discussion may suggest similar alternative control measures for Perreyia sp. larvae toxicity.

Acknowledgements.- The authors are grateful to Dr. Fernando Zanotta da Cruz, retired professor from the Department of Entomology, UFRGS, for the identification of the insect.

\section{REFERENCES}

Allen T.C. 1992. Hematoxylin and eosin, p.53-58. In: Prophet E.B., Mills B., Arrington J.B. \& Sobin L.H. (Eds), Laboratory Methods in Histotechnology. American Registry of Pathology, Washington, DC. 
Badylak S.F. 1988. Coagulation disorders and liver disease. Vet. Clin. North Am., Smal Anim. Pract. 18:87-93.

Camargo O.R. 1955. Contribuição ao estudo do Tenthredinideo Mata Porcos, Paraperreyia dorsuaria (Know, 1899), no Rio Grande do Sul. Thesis, Universidade Federal do Rio Grande do Sul, Porto Alegre.

Cheeke P.R. 1998. Natural Toxicants in Feeds, Forages, and Poisonous Plants. $2^{\text {nd }}$ ed. Interstate Publishers, Danville. 479p.

Cheville N.F. 1994. Pathologic metabolism and growth, p.125-274. In: Ibid. (Ed.), Ultrastructural Pathology: An introduction to interpretation. Iowa State University Press, Ames.

Colodel E.M., Driemeier D. \& Pilati C. 2000. Intoxicação experimental pelos frutos de Xanthium cavanillesii (Asteraceae) em bovinos. Pesq. Vet. Bras. 20:31-38.

Cornelius C.E. 1989. Liver function, p.364-397. In: Kaneko J.J. (Ed.), Clinical Biochemistry of Domestic Animals. Academic Press, San Diego.

Dadswell L.P., Abott W.D. \& McKenzie R.A. 1985. The occurrence, cost and control of sawfly larval (Lophyrotoma interrupta) poisoning of cattle in Queensland 1972-1981. Aust. Vet. J. 62, 94-97.

Dutra F. 1997. Intoxicação por larvas de Perreyia flavipes. Caracterização da doença e biologia do inseto. Dissertação, Universidade Federal de Pelotas, RS.

Dutra F., Riet-Correa F., Mendez M.C. \& Paiva N. 1997. Poisoning of cattle and sheep in Uruguay by sawfly (Perreyia flavipes) larvae. Vet. Human Toxicol. 39:281-286.

Holloway J.K. 1968. Proyectos en el control biologico de las malas hierbas, p.761-785. In: DeBach P. (Ed.), Control Biologico de las Plagas de Insectos y Malas Hierbas. Compañia Editorial Continental, Buenos Aires.

Jackson A.R.B., McInnes A., Falconer I.R. \& Runnegar M.T. 1984. Clinical and pathological changes in sheep experimentally poisoned by the bluegreen alga Microcystis aeruginosa. Vet. Pathol. 21:102-113.

Jonck F., Casagrande R.A., Froehlich D.L., Ribeiro Jr D.P. \& Gava A. 2010. Intoxicação espontânea pelas larvas de Perreyia flavipes (Pergidae) em suínos no estado de Santa Catarina. Pesq. Vet. Bras. 30(12):1017-1020.

Kannan R., Oelrichs P.B., Thamsborg S.T. \& Willians D.H. 1988. Identification of the octapeptide lophyrotomin in the European birch sawfly (Arge pullata). Toxicon 26:224-226.
Kellerman T.S., Coetzer J.A.W., Naudé T.W. \& Botha C.J. 2005. Plant Poisoning and Mycotoxicoses of Livestock in Southern Africa. $2^{\text {nd }}$ ed. Oxford University Press, Cape Town.

Loretti A.P., Bezerra Jr P.S., Ilha M.R.S., Barros S.S. \& Barros C.S.L. 1999. Intoxicação experimental pelos frutos de Xanthium cavanillesii (Asteraceae) em ovinos. Pesq. Vet. Bras. 19:71-78.

McKenzie R.A., Rogers R.J. \& Oelrichs P.B. 1985. Sawfly larvae poisoning of cattle in Queensland. Proceedings of the Australia-U.S.A. Poisonous Plants Symposium, Brisbane, p.524-532.

Oelrichs P.B., MacLeod J.K., Seawright A.A., Moore M.R., NG J.C., Dutra F., Riet-Correa F., Mendez M.C. \& Thamsborg S.M. 1999. Unique toxic peptides isolated from sawfly larvae in three continents. Toxicon 37:537544.

Radostits O.M., Gay C.C., Blood D.C \& Hinchcliff D.C. 2002. Clínica Veterinária: Um tratado de doença dos bovinos, ovinos, suínos, caprinos e eqüinos. 9a ed. Guanabara Koogan, Rio de Janeiro.

Raymundo D.L., Bezerra Jr P.S., Bandarra P.M., Pedroso P.M.O., Oliveira E.C., Pescador C.A. \& Driemeier D. 2008. Spontaneous poisoning by larvae of Perreyia flavipes (Pergidae) in sheep. Pesq. Vet. Bras. 28:19-22.

Raymundo D.L., Bezerra Jr P.S., Bandarra P.M., Santos A.S., Sonne L., Pavarini S.P., Correa A.M.R., Dias M.M. \& Driemeier D. 2009. Intoxicação espontânea pelas larvas de Perreyia flavipes em bovinos no Estado de Santa Catarina, Brasil. Ciência Rural 39:163-166.

Riet-Correa F., Schild A.L., Lemos R.A.A. \& Borges J.R.J. 2007. Doenças de Ruminantes e Eqüídeos. Vol.2. 3aㅡ ed. Pallotti, Santa Maria. 694p.

Smith D.R. 1990. A synopsis of the sawflies (Hymenoptera, Symphyta) of America South of the United States: Pergidae. Revta Bras. Entomol. 34:7200.

Soares M.P., Riet-Correa F., Smith D.R., Pereira Soares M., Mendez M.C. \& Brandolt A.L. 2001. Experimental intoxication by larvae of Perreyia flavipes Know, 1899 (Hymenoptera: Pergidae) in pigs and some aspects on its biology. Toxicon 39:669-678.

Soares M.P., Quevedo P.S. \& Schild A.L. 2008. Intoxicação por larvas de Perreyia flavipes em bovinos na região sul do Rio Grande do Sul. Pesq. Vet. Bras. 28(01):19-22.

Thamsborg S.M., Jorgensen R.J. \& Brummerstedt E. 1987. Sawfly poisoning in sheep and goats. Vet. Rec. 121:253-255. 